\title{
PENERAPAN PERUBAHAN UKURAN MATA JARING DALAM PENANGKAPAN IKAN TERBANG SECARA BERKELANJUTAN DI KECAMATAN SENDANA KABUPATEN MAJENE
}

\author{
Najamuddin ${ }^{1)}$, Andi Assir ${ }^{1)}$, Mahfud Palo ${ }^{1)}$ dan Andi Asni ${ }^{2)}$ \\ 1) PS Pemanfaatan Sumberdaya Perikanan FPIK UNHAS \\ ${ }^{2)}$ PS Pemanfaatan Sumberdaya Perikanan FPIK UMI \\ Korespondensi: najamuddin@unhas.ac.id
}

Diterima: tanggal 2 September 2018; Disetujui 31 November 2018

\begin{abstract}
Catching flying fish in Sendana Majene Subdistrict is carried out continuously with gill nets 1-1.5 inches. The catch of flying fish is mostly still young fish (not yet worth catching). The demand for flying fish is quite high due to the existence of special stalls of smoke fly fish around fishing settlements. Apart from smoke flying fish, dried flying fish are also sold as souvenirs. Therefore, fishermen will continue to increase production. Various results of research and field observations show that gill net is able to catch flying fish well but the size of fish caught is dominated by young fish. The effort to increase the net mesh size to 1.5 inches resulted in the diminishing number of young flying fish. Catching flying fish in Majene waters is generally carried out with drifting gill nets with mesh sizes of 1 and 1.25 inches which are very intensive every fishing season while L50 $(11.92 \mathrm{~cm})$ and $\operatorname{Lm}(13.59 \mathrm{~cm})$ for 1 inch more net mesh size were smaller compared to the length of the first gonad maturity, in this case most of the catch is still classified as young fish (Palo, 2009). Partners are a group of flying fish fishermen. Partner problems, flying fish production is getting smaller, group capacity is not strong and group management is still weak. Partners have not been able to obtain assistance facilities from various community empowerment programs carried out by the government. The approach to be used in this service includes: identification, observation, counseling, demonstration, construction, application, assistance, field observation and evaluation monitoring. Indicators of the success of activities are measured based on the results of the application of technology compared to the results of fishing gear commonly used by fishermen. Implementation of service includes counseling, construction of fishing gear, fishing operations and assistance has been going well. The size of 1.5-inch mesh is only able to catch flying fish in a limited amount, while the size of the 1.25-inch mesh can catch flying fish in relatively large numbers. Flying fish caught with 1.25-inch mesh size has passed the size of the first gonad mature so that it supports sustainable fisheries.
\end{abstract}

Keywords: gill fly fish net, sustainable, group management 


\begin{abstract}
ABSTRAK
Penangkapan ikan terbang di Kecamatan Sendana Majene dilakukan secara terus menerus dengan jarring insang mata jaring 1-1,5 inci. Hasil tangkapan ikan terbang sebahagian besar masih ikan muda (belum layak tangkap). Permintaan terhadap ikan terbang cukup tinggi akibat adanya warung khusus ikan terbang asap di sekitar pemukiman nelayan. Selain ikan terbang asap, ikan terbang kering juga dijual sebagai souvenir. Oleh karena itu peningkatan produksi akan terus dilakukan nelayan. Berbagai hasil penelitian dan pengamatan lapangan menunjukkan bahwa gill net mampu menangkap ikan terbang dengan baik tetapi ukuran ikan yang tertangkap didominasi oleh ikan-ikan yang masih muda. Upaya meningkatan ukuran mata jarring menjadi 1,5 inci menghasilkan semakin berkurangnya ikan terbang yang masih muda. Penangkapan ikan terbang di perairan Majene umumnya dilakukan dengan jaring insang hanyut ukuran mata jaring 1 dan 1,25 inci yang sangat intensif setiap musim penangkapan sementara $\mathrm{L}_{50}(11,92 \mathrm{~cm})$ maupun $\mathrm{Lm}(13,59 \mathrm{~cm})$ untuk jaring ukuran mata 1 inci lebih kecil dibanding panjang pertama kali matang gonad, dalam hal ini sebagian besar hasil tangkapan masih tergolong ikan muda (Palo, 2009). Mitra adalah kelompok nelayan ikan terbang. Permasalahan mitra, produksi ikan terbang semakin kecil, kapasitas kelompok tidak kuat dan manajemen kelompok juga masih lemah. Mitra belum mampu mendapatkan fasilitas bantuan dari berbagai program pemberdayaan masyarakat yang dilakukan pemerintah. Pendekatan yang akan digunakan dalam pengabdian ini meliputi : identifkasi, observasi, penyuluhan, demonstrasi, konstruksi, penerapan, pendampingan, pengamatan lapangan dan monitoring evaluasi. Indikator keberhasilan kegiatan diukur berdasarkan hasil penerapan teknologi di bandingkan dengan hasil alat tangkap yang umum digunakan nelayan. Pelaksanaan pengabdian meliputi penyuluhan, konstruksi alat tangkap, operasi penangkapan ikan dan pendampingannya telah berjalan dengan baik. Ukuran mata jaring 1,5 inci hanya mampu menangkap ikan terbang dalam jumlah terbatas, sementara ukuran mata jaring 1,25 inci mampu menangkap ikan terbang dalam jumlah relative banyak. Ikan terbang yang tertangkap dengan ukuran mata jaring 1,25 inci sudah melewati ukuran pertama kali matang gonad sehingga menunjang perikanan yang berkelanjutan.
\end{abstract}

Kata kunci : gill net ikan terbang, berkelanjutan, manajemen kelompok

\section{PENDAHULUAN}

Keberhasilan dari suatu penelitian apabila dapat dirasakan manfaatnya oleh masyarakat ketika diaplikasikan di lapangan. Tanggung jawab seorang peneliti bukan hanya pada penemuan teknologi tertentu akan tetapi yang paling urgen adalah membantu masyarakat dalam mengatasi permasalahan yang dihadapinya terutama dapat meningkatkan pendapatan keluarganya. Kenyataan menunjukkan, sebahagian besar hasil penelitian hanya dalam bentuk laporan atau publikasi jurnal yang

Keberadaan kelompok nelayan sebagai bentuk pemberdayaan masyarakat yang dilakukan pemerintah cenderung tidak tidak dapat diakses maupun diaplikasikan oleh masyarakat yang membutuhkan. Kondisi lapangan sangat membutuhkan sentuhan paket teknologi dalam upaya meningkatkan taraf hidup mereka. Tanpa sentuhan teknologi tertentu, rasanya akan sangat sulit bagi masyarakat untuk meningkatkan taraf hidup mereka. Masyarakat nelayan cenderung melakukan kegiatan seharihari secara rutin tanpa ada upaya perbaikan-perbaikan, baik dari segi teknologi, produksi, manajemen usaha maupun keberlanjutan sumberdayanya.

berjalan dengan baik akibat kelemahan manajemen kelompok. Tujuan pemerintah melakukan pemberdayaan 
masyarakat melalui kelompok adalah untuk meningkatkan semangat bekerjasama di tengah masyarakat, yang cenderung semakin ditinggalkan. Kecenderungan masyarakat yang semakin bekerja sendiri dan meninggalkan budaya gotongroyong merupakan factor penghambat kemajuan kelompok.

Berbagai hasil penelitian dan pengamatan lapangan menunjukkan bahwa gill net mampu menangkap ikan terbang dengan baik tetapi ukuran ikan yang tertangkap didominasi oleh ikanikan yang masih muda. Upaya meningkatan ukuran mata jarring menjadi 1,5 inci menghasilkan semakin berkurangnya ikan terbang yang masih muda.

Penangkapan ikan terbang di perairan Majene umumnya dilakukan dengan jaring insang hanyut ukuran mata jaring 1 dan 1,25 inci yang sangat intensif setiap musim penangkapan sementara $\mathrm{L}_{50}(11,92 \mathrm{~cm})$ maupun $\mathrm{Lm}$ $(13,59 \mathrm{~cm})$ untuk jaring ukuran mata 1 inci lebih kecil dibanding panjang pertama kali matang gonad, dalam hal ini sebagian besar hasil tangkapan masih tergolong ikan muda (Palo, 2009). Menurut Ali (2005), sebesar 86,45\% ikan terbang di Selat Makassar tertangkap dengan jaring insang dengan ukuran mata jaring 1, 1,25 dan 1,5 inci. Jaring insang yang memiliki ukuran mata jaring tersebut menangkap ikan terbang yang matang gonad atau sedang memijah dan sebagian kecil ikan muda. Selanjutnya dikatakan analisis panjang awal matang gonad ikan terbang Hirundichthys oxycephalus diperoleh rata-rata panjang cagak pertama kali matang gonad adalah $15,15 \mathrm{~cm}$.

\section{A. Analisis Situasi}

Kelompok Nelayan Baru Bi'ar berlokasi di Lingkungan Somba Selatan, Kelurahan Mosso, Kecamatan Sendana Kabupaten Majene. Kelompok nelayan ini berusaha dalam bidang penangkapan ikan terbang. Kelompok ini dibentuk atas dasar kebersamaan untuk sebuah komitmen mengembangkan potensi daerah untuk meningkatkan kesejahteraan masyarakat. Kelompok ini, secara geografis berada di Lingkungan Somba Selatan, Kelurahan Mosso, Kecamatan Sendana, Kabupaten Majene, Selat Makassar yang merupakan area yang memiliki potensi sumberdaya ikan terbang. Kelompok ini beranggotakan 10 orang nelayan ikan terbang yang diketuai oleh Bapak Jainuddin. Menangkap ikan terbang merupakan mata pencaharian utama para anggotanya.

Kelompok ini belum pernah mengelola bantuan dana dari Program Pemberdayaan Masyarakat Pesisir untuk pengembangan usaha penangkapan ikan terbang. Permasalahan kapasitas kelompok dan manajemen usaha dan manajemen kelompok membuat kelompok ini belum mampu mendapatkan bantuan pemerintah, yang berakibat pada semakin lemahnya kapasitas kelompok. 
Jenis ikan yang banyak ditangkap adalah ikan terbang. Kondisi Laut Selat Makassar yang semakin terbuka dan ombak besar disertai dengan tekanan eksploitasi tinggi membuat nelayan semakin kesulitan dalam meningkatkan pendapatan keluarga. .

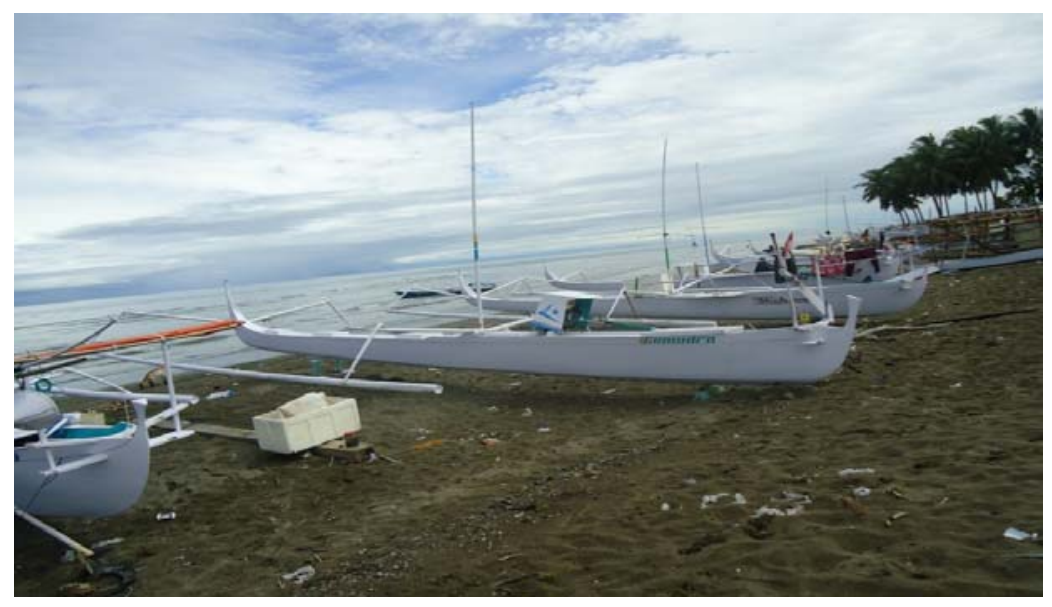

Gambar 1. Kondisi kapal nelayan ikan terbang di Kab. Majene

Kapal penangkap ikan terbang yang digunakan nelayan relative kecil dengan ABK 1-2 orang dengan daerah penangkapan di wilayah pesisir $<4$ mil. Kondisi aramada penangkap ikan seperti terlihat pada Gambar 1. Kondisi hasil tangkapan sehari-hari cenderung berfluktuasi sesuai musim. Ikan-ikan yang diperoleh akan dijual dalam bentuk segar, akan tetapi kalau tidak habis terjual akan dikeringkan supaya dapat bertahan lebih lama. Aktivitas penangkapan ikan dilakukan setiap hari. Kelompok nelayan mitra hanya sebatas memproduksi ikan segar dan kering yang dijual ke pedagang pengumpul atau warung di sekitarnya dengan harga berkisar Rp. 10000 - Rp. 15000 per kg ikan.

Keberadaan kelompok nelayan ini berdampak pada pengembangan komoditas ikan terbang yang menjadi komoditas andalan hasil Laut di Kecamatan Sendana Kabupaten Majene untuk membantu meningkatkan pendapatan daerah. Selain itu, keberadaan kelompok ini memberikan dampak positif bagi masyarakat sekitar.

\section{B. Permasalahan Mitra}

Masalah yang dihadapi mitra adalah semakin berkurangnya potensi ikan terbang di Laut serta ukuran yang semakin kecil sehingga nelayan cenderung menggunakan ukuran mata jarring yang semakin kecil. Kondisi alat penangkapan yang tidak selektif terhadap ikan muda akan mempercepat proses penurunan stok ikan terbang di Laut.

Masalah lain yang dihadapi adalah harga yang sering anjlok apalagi pada saat hasil panen melimpah, masih kurangnya pengetahuan dan keterampilan petani dalam penanganan 
pasca panen dan pengolahan produk ikan yang dapat meningkatkan nilai jual, sehingga pendapatan juga meningkat. Cara penanganan ikan pasca panen yang kurang baik, misalnya hanya dikeringkan dan dijual segar sementara belum dikenal diversifikasi produk olahan ikan untuk meningkatkan nilai tambah.

Masalah manajemen kelompok merupakan hal mendesak dalam pemberdayaan masyarakat yang dilakukan selama ini. Pemberdayaan berbasis kelompok dimaksudkan agar masyarakat secara berkelompok dapat berkembang secara bersama-sama. Namun dalam prakteknya, kebersamaan tersebut cenderung kurang terbangun akibat krisis kepercayaan dan manajemen.

Masih minimnya pengetahuan dan keterampilan masyarakat tentang alternative alat penangkapan ikan serta keberlanjutan usaha penangkapan ikan, menjadi masalah prioritas yang dicarikan solusinya. Kelompok ini berharap adanya transfer pengetahuan dan keterampilan dalam penangkapan ikan, dengan adanya program IPTEKS bagi Masyarakat ( $\mathrm{IbM})$ ini. Diharapkan solusi yang ditawarkan dapat memberikan hasil yang maksimal yang berdampak pada peningkatan pendapatan petani rumput laut dan menekan angka pengangguran karena dapat membuka lahan kerja baru pada bidang penangkapan ikan khususnya dan bisa meningkatkan

setiap hari operasi penangkapan ikan untuk menghindari pengaruh posisi jaring. Data yang dikumpulkan adalah pendapatan asli daerah Kabupaten Majene pada umumnya.

\section{METODE PENELITIAN}

Kegiatan pengabdian masyarakat ini dilakukan di Desa Somba, Kecamatan Sendana, Kabupaten Majene pada bulan Juli sampai Oktober 2017. Rangkaian kegiatan pengabdian meliputi : penyuluhan, penyerahan bahan pembuatan jarring insang ikan terbang, konsruksi alat penangkapan ikan dan pendampingan, pengoperasian alat penangkapan ikan.

Bahan dan alat yang dibutuhkan meliputi : jarring monofilament ukuran mata jarring 1, 1,25 dan 1,5 inci, pelampung, pemberat, tali temali, coban dan nilon monofilament. Satu unit alat penangkap ikan terbang.

Penyuluhan dilakukan di ruang pertemuan Desa dengan melibatkan masyarakat nelayan. Metode penyuluhan meliputi penyampaian materi meliputi penangkapan ikan terbang berkelanjutan, daerah penangkapan ikan terbang dan manajemen kelompok nelayan. Pada penyuluhan ini juga dijelaskan rencana penerapan teknologi di laut dan kontruksi jarring insang yang akan digunakan. Konstruksi jarring insang dilakukan oleh anggota kelompok nelayan dengan 3 ukuran mata jarring berbeda.

Setelah pemaparan materi dilanjutkan dengan diskusi terkait penangkapan ikan terbang dan masalah yang dihadapi masyakat nelayan. Penerapan teknologi dengan mengoperasikan 3 ukuran mata jarring insang yang disambung pada 1 unit alat penangkap ikan terbang. Posisi masingmasing ukuran mata jarring diacak jumlah ikan terbang yang tertangkap pada masing-masing ukuran mata jarring. Data pelaksanaan kegiatan dianalisis secara deskriptif dan hasil 
penerapan teknologi dianalisis dilaksanakan pada tanggal 14 Juli 2017 menggunakan uti $t$ student dengan bertempat di Desa Somba Kecamatan tingkat kepercayaan 95\%.

\section{HASIL DAN PEMBAHASAN}

Kegiatan utama yang dilakukan adalah pelaksanaan pengabdian masyarakat yang melibatkan tim pengabdi dan masyarakat kelompok sasaran serta masyarakat nelayan Sendana Kabupaten Majene. Rangkaian kegiatan pengabdian meliputi : penyuluhan, penyerahan bahan pembuatan jarring insang ikan terbang, konsruksi alat penangkapan ikan dan pendampingan, pengoperasian alat penangkapan ikan dan pendampingan, lainnya. Kegiatan penyuluhan

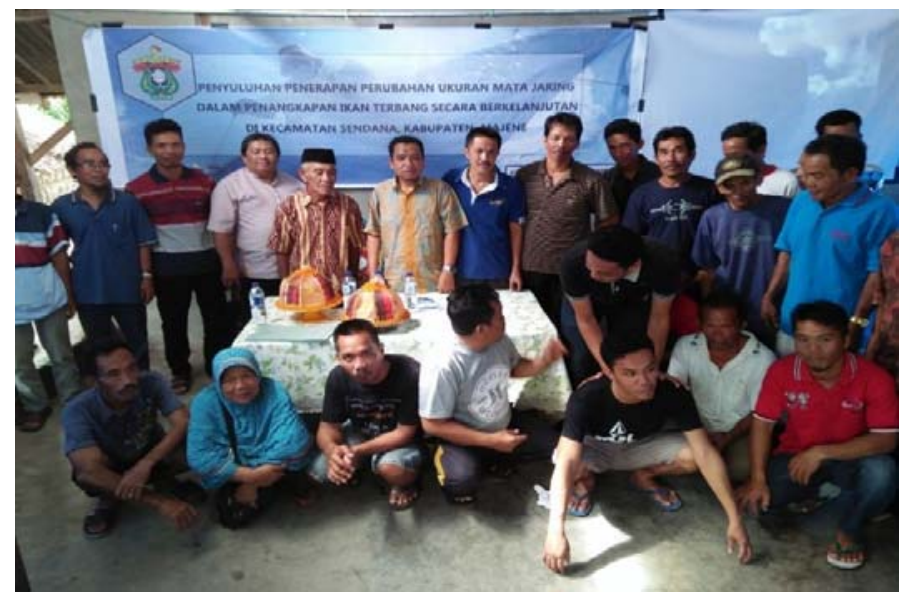

Gambar 3. Kegiatan Pengabdian Masyarakat di Kecamatan Sendana Kabupaten Majene

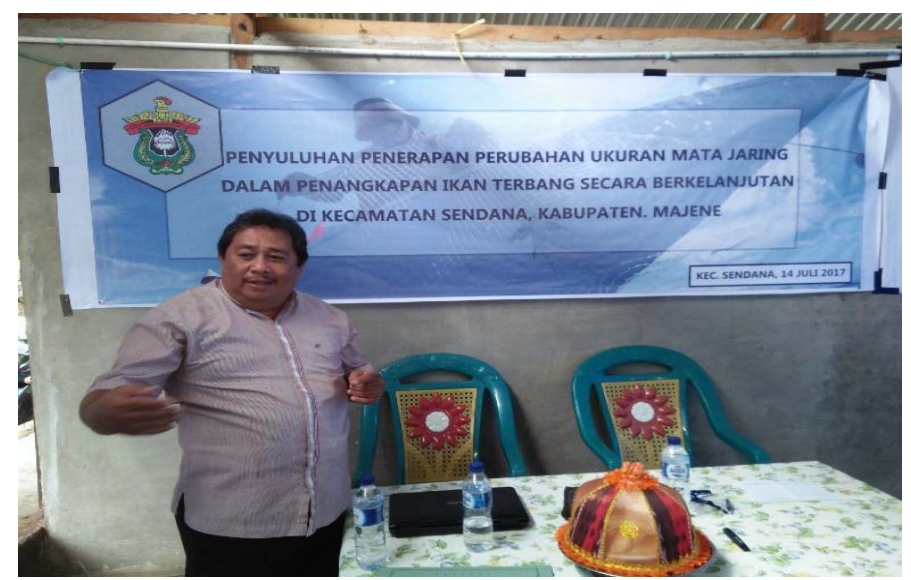

Gambar 4. Pemateri Dr. Ir. Andi Assir 


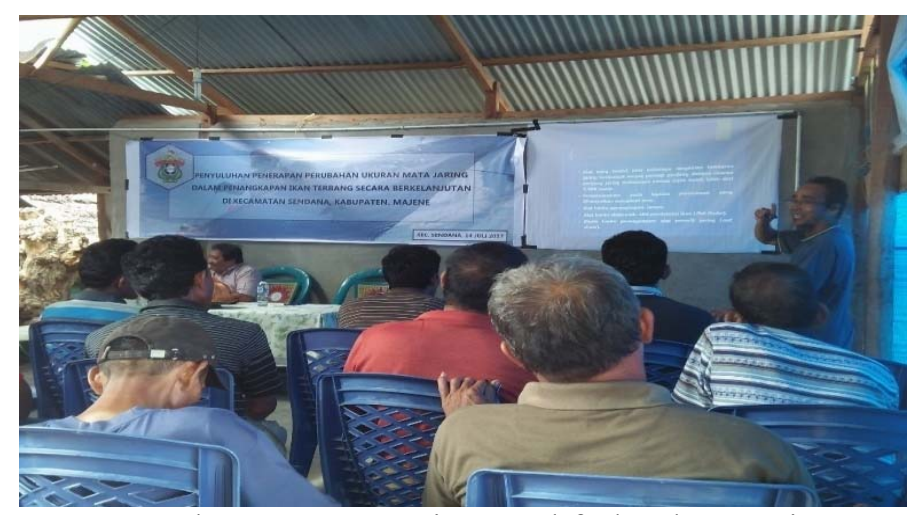

Gambar 5. Pemateri Ir. Mahfud Palo, M.Si.

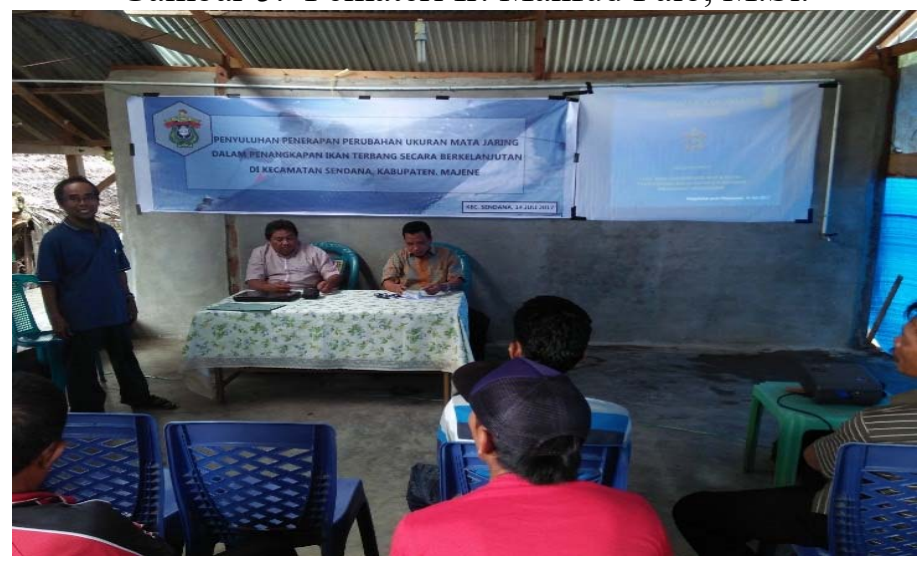

Gambar 6. Pemateri Prof. Dr. Najamuddin, M.Sc

Kegiatan penyuluhan di Somba terbang ukurannya semakin kecil, jumlah Kec Sendana Majene pada tanggal 14 ikan hasil tangkapan semakin berkurang Juli 2017. Peserta kegiatan sebanyak 22 dan daerah penangkapan semakin jauh orang yang terdiri dari kelompok nelayan dari pantai. Kondisi ini terjadi Karena Bi'ar dan partisipan nelayan lainnya serta nelayan tidak memperhatikan ukuran melibatkan 4 orang mahasiswa prodi mata jarring yang seharusnya digunakan. PSP. Ada 3 orang pemateri yaitu Prof. Nelayan hanya berfikir bagaimana Najamuddin, Dr. Andi Assir dan Ir. caranya supaya ikan yang diperoleh Mahfud Palo. jumlahnya tetap banyak. Untuk Materi I disampaikan oleh Ir. mempertahankan supaya ikan tetap Mahfud Palo, M.Si dengan topik banyak maka seharusnya kita Penangkapan ikan terbang berkelanjutan. menggunakan matajaring yang membuat Pada materi ini dijelaskan kondisi ikan yang tertangkap hanya ikan yang perikanan ikan terbang di lokasi sudah pernah bertelur. Selain itu, penyuluhan dan bagaimana kondisinya telurnya semestinya tidak boleh diambil, dari dulu sampai sekarang. Ada supaya dapat menghasilkan kembali kecenderungan bahwa sumberdaya ikan ikan-ikan kecil. 
Materi ke 2 Dr.Ir. Andi Assir target dasarnya. Oleh Karena itu, Marimba, M.Sc dengan Judul masyarakat harus menyadari kondisi ini Manajemen daerah penangkapan ikan terbang. Daerah penangkapan merupakan tempat dimana nelayan melakukan penangkapan ikan. Untuk dapat menangkap ikan yang tetap banyak diperlukan pengelolaan daerah penangkapan. Pergerakan ikan di laut memiliki pola tertentu dan kalau itu diketahui maka nelayan tidak akan sulit mendapatkan ikan.

Materi ke 3 oleh Prof. Dr.Ir. Najamuddin, M.Sc. dengan judul Manajemen kelompok. Urgensi pembentukan kelompok adalah menumbuhkan kembali jiwa gotong royong yang akhir-akhir ini cenderung semakin terkikis. Kebersamaan melalui gotong royong merupakan ciri khas bangsa Indonesia sejak dulu kala, terutama di daerah pedesaan. Untuk mengembalikan jiwa kebersamaan tersebut maka pemerintah hanya memberikan bantuan kepada kelompok masyarakat, tidak ada yang sifatnya perorangan. Permasalah yang terjadi, dimana sebahagian besar kelompok yang ada tidak dibentuk atas prinsip kebersamaan, melainkan atas dasar untuk mendapatkan bantuan. Akibatnya, bantuan yang dikucurkan pemerintah dan berusaha memperbaikinya.

\section{Penangkapan Ikan}

Alat penangkapan ikan berupa jarring insang hanyut dengan ukuran mata jarring 1,5 inci digunakan bersama nelayan untuk mengevaluasi bagaimana penampilannya di lapangan. Setelah dilakukan uji coba, ternyata ikan-ikan terbang yang tertangkap sangat sedikit dan juga berbeda jenis dengan yang menjadi target tangkapan nelayan. Oleh karena itu dilakukan modifikasi ukuran mata jarring menjadi 1,25 inci.

Penerapan ukuran mata jaring dilakukan bersama-sama dengan kelompok nelayan dengan menggunakan 2 ukuran mata jaring, yaitu 1 inci dan 1,25 inci. Nelayan cenderung menggunakan ukuran mata jarring 1 inci, sehingga dalam uji coba menggunakan ukuran mata jarring lebih besar dari ukuran mata jarring nelayan. Parameter yang diamati adalah jumlah ikan yang tertangkap pada masing-masing ukuran mata jaring. Hasilnya akan dibandingkan dengan menggunakan uji statistika dengan t-student. Data jumlah ikan yang tertangkap disajikan pada Tabel 3. 
Tabel 3. Data jumlah ikan terbang hasil tangkapan jaring sesuai ukuran mata

\begin{tabular}{cc}
\hline Mesh size 1 inci & Mesh size 1,25 inci \\
\hline 1.00 & 3.00 \\
7.00 & 5.00 \\
2.00 & 3.00 \\
11.00 & 9.00 \\
2.00 & 4.00 \\
3.00 & 2.00 \\
1.00 & 3.00 \\
2.00 & 7.00 \\
13.00 & 6.00 \\
7.00 & 19.00 \\
18.00 & 23.00 \\
10.00 & 25.00 \\
\hline
\end{tabular}

Tabel 4. Analisis statistika dengan uji t-student, t-Test: Two-Sample Assuming Equal Variances

\begin{tabular}{lrr}
\hline & Variable 1 & Variable 2 \\
\hline Mean & 6.416667 & 9.083333 \\
Variance & 30.99242 & 69.35606 \\
Observations & 12 & 12 \\
Pooled Variance & 50.17424 & \\
Hypothesized Mean & 0 & \\
Difference & & \\
df & 22 & \\
t Stat & -0.92216 & \\
$\mathrm{P}(\mathrm{T}<=\mathrm{t})$ one-tail & 0.183225 & \\
t Critical one-tail & 1.717144 & \\
$\mathrm{P}(\mathrm{T}<=\mathrm{t})$ two-tail & 0.366451 & \\
$\mathrm{t}$ Critical two-tail & 2.073873 & \\
\hline
\end{tabular}


Hasil pengoperasian jaring insang ikan terbang sebanyak 10 kali menunjukkan bahwa terdapat variasi jumlah ikan yang tertangkap dengan ukuran mata jarring berbeda. Namun, jumlah ikan terbang yang tertangkan secara keseluruhan menujukkan bahwa jarring insang dengan ukuran mata jarring 1,25 inci memperoleh jumlah ikan lebih banyak dibandingkan dengan jarring insang ukuran mata jarring 1 inci.

Hasil analisis statistika menunjukkan bahwa hasil tangkapan jarring insang 1,25 inci tidak berbeda nyata $(\mathrm{P}>0,05)$ dari pada jaring insang ukuran mata jarring 1 inci. Hal ini menunjukkan bahwa ada kecenderungan ukuran ikan terbang lebih besar dari sebelumnya, sehingga hasil tangkapan jarring insang yang lebih besar mata jaringnya mendapatkan hasil tangkapan yang lebih banyak walaupun secara statistic tidak nyata. Hal sesuai pendapat Najamuddin (2014) bahwa prinsip penangkapan ikan dengan jarring insang disesuaikan dengan ukuran ikan yang akan ditangkap. Dalam rangka mempertahankan keberlanjutan usaha penangkapan ikan terbang maka ukuran mata jaring seharusnya diperbesar dari ukuran 1 inci menjadi 1,25 inci.

\section{KESIMPULAN}

Pelaksanaan pengabdian meliputi penyuluhan, konstruksi alat tangkap, operasi penangkapan ikan dan pendampingannya telah berjalan dengan baik. Ukuran mata jaring 1,5 inci hanya mampu menangkap ikan terbang dalam jumlah terbatas, sementara ukuran mata jaring 1,25 inci mampu menangkap ikan terbang dalam jumlah relative banyak. Ikan terbang yang tertangkap dengan ukuran mata jarring 1,25 inci sudah melewati ukuran pertama kali matang gonad sehingga menunjang perikanan yang berkelanjutan.

\section{SARAN}

Untuk mempertahankan keberlanjutan penangkapan ikan terbang maka para nelayan sebaiknya memperbesar ukuran mata jarring dari 1 inci menjadi 1,25 inci. Sebaiknya kegiatan penangkapan ikan terbang tidak dilakukan pada saat ikan terbang memijah untuk mencegah penurunan stok ikan terbang.

\section{UCAPAN TERIMA KASIH}

Penulis mengucaptan terima kasih kepada Rektor Universitas Hasanuddin beserta jajarannya atas bantuan dana pelaksanaan kegiatan ini. Ucapan terima kasih juga disampaikan kepada kelompok nelayan ikan terbang di lokasi pengabdian atas bantuan dan kerjasamanya selama pelaksanaan kegiatan.

\section{DAFTAR PUSTAKA}

Ali, S.A., 2005. Kondisi Sediaan dan Keragaman Populasi Ikan Terbang (Hirundichthys oxycephalus), 1852) di Laut Flores dan Selat Makassar. Disertasi, PASCASARJANA-UH.

Ali, S.A. dan M.N. Nessa, 2006. Status Ilmu Pengetahuan Ikan Terbang di Indonesia. Prosiding. Lokakarya 
Nasional Perikanan Ikan Terbang. Najamuddin. 2012. Rancangbangun Alat Makassar, 20-21 September 2005. Penangkap Ikan. Arus Timur. UNHAS-DKP-PPO LIPI Makassar.

Ali, S.A., M.N. Nessa, M.I. Djawad dan Najamuddin, Palo, M., dan Taufik, M. S.B.A. Omar, 2005. Analisis Struktur Populasi Ikan Terbang (Hirundichthys oxycephalus) dari Laut Flores dan Selat Makassar untuk Penentuan Wilayah Pengelolaan dan Konservasi. Torani, 15 (2) 136-144

Chang H.Y., B. K. CHO, J. S. Park and W. L. Lee, 2007. Mesh selectivity of gill nets for silver promfret (Pampus argenteus). J. Kor. Soc. Fish. Tech., 43(3), 169-175, 2007

Fitrianti R.S., M. M. Kamal dan R. Kurnia, 2014. Analisis Keberlanjutan Perikanan Ikan Terbang di Kabupaten Takalar, Sulawesi Selatan.Depik, 3(2): 118127

Fridman, A.L., 1988. Calculation for Fishing Gear Designs. FAO-UN, Rome 2010. Gill net design for flying fish in Majene District. Prosiding Seminar Internasional, Makassar 22 Nopember 2010. Hal 524-535.

Najamuddin, Palo, M., dan Affandi, A. 2011. Rancangbangun jaring insang ikan terbang di Perairan Kabupaten Takalar, Sulawesi Selatan. Prosiding Seminar Nasional Perikanan dan Kelautan, Pekanbaru, 26-27 Okktober 2011. Hal 90-99.

Nomura, M., 1989. Outline of Fishing Gear and Methods. JICA, Tokyo.

Palo, M., 2009. Kajian Penangkapan Ikan Terbang (Exocoetidae) dengan Jaring Insang Hanyut di Perairan Kecamatan Sendana Kabupaten Majene Sulawesi Barat. Tesis, Program Pascasarjana Unhas, Makassar 